\title{
Meaning Conception and Perception in Political Campaign Adverts - A Multimodal Discourse Approach
}

\author{
M. S. Abdullahi - Idiagbon ${ }^{1}$ \\ ${ }^{1}$ University of Ilorin, Ilorin, Kwara State, Nigeria \\ Correspondence: M. S. Abdullahi - Idiagbon (Ph.D), University of Ilorin, Ilorin, Kwara State, Nigeria. Tel: \\ 234-080-3368-8515. E-mail: msidiagbon@gmail.com
}

Received: October 24, 2012 Accepted: January 30, 2013 Online Published: February 22, 2013

doi:10.5539/ells.v3n1p84 URL: http://dx.doi.org/10.5539/ells.v3n1p84

\begin{abstract}
The complexity of human thoughts is manifested in his words, actions, and other meaning-signalling devices. The use of language or graphical material like motion or motionless pictures/images as well as natural or electronic sound is imbued with information, ideology and properties capable of effectively conveying implicit and explicit meaning to the target audience. A multimodal discourse, hence, becomes a viable means of demonstrating all these qualities. Language-use, especially in politics, turns an individual or a state's instrument used to arouse sentiments, win sympathy and trigger the sense of submission and followership. Thus, an appreciable quantum of meaning of the speaker's utterances can be strongly enhanced by a multimodal discourse which makes use of multiple semiotic resources like language, visual images, sound, space, etc. However, language or other media through which we communicate do not convey the 'objective truth' as it is made to believe; there is always subjectivity in the so-called objectivity. Critical Discourse Analysis (CDA) warns against the assumption of objectivity notwithstanding the multimodal means of such discourse, and it further sensitises people on ways of politicking with language. CDA goes beyond the borders of text and other semiotic means employed in the process of encoding a campaign advert. to perceiving meaning as bi-directional and that the actual meaning is hidden but retrievable from many contending factors like social class, ideologies, ethnicity, religion and interests, etc. which are not even necessarily found in words, images, sound, music and other semiotic resources woven to construct such discourse. This paper investigates a political campaign television advert of Nigerian's President Goodluck Jonathan in his desperate move to return as the President of Nigeria using, essentially, CDA approach to explore the multimodality of this discourse construction. The paper further explores the perception of this campaign advert not only on the basis of audience's sophistication and individuality but also on what the speech seeks to achieve taking into account both linguistic and non-linguistic communicative facilities.
\end{abstract}

Keywords: meaning, campaign, adverts, multimodal discourse

"I was not born rich. I had no shoes, no school bag; I carried my books in my hands to school. I am one of you. I have no enemies to fight. I never thought I would be where I am today. If I can make it, you can make it! I am Goodluck Jonathan."

President Goodluck Jonathan

\section{Introduction}

The idea of this paper was triggered by a facebook comment I saw on my homepage. It was pasted by one of my former students presently on a one-year mandatory National Youth Service for the Nigerian graduates below thirty years of age. Below is his sarcastic comment on President Jonathan's brief television campaign advert rendered in Nigerian Pidgin English (NPE):

"I was not born rich." "Before nko? No be fisherman pikin u be? (What else does one expect; after all, you are a fisherman's son)

"I had no shoes." Of course, u are from riverine area, no be canoe u dey use go sch., wetin u wan use shoe do? (Of course, you are from a riverine area. You go to school on canoe. So you don't have business with shoe in the first place.) 
"I am one of you." Na lie, why u no dey live in ghetto like we people. (That is not true! Why then don't you live in ghetto like us if you are truly one of us?)

"I have no enemies to fight." Na true be dat, $u$ don eliminate dem finish. (That is true! Afterall, you have eliminated all of them)

"I never imagined I would be where I am today." Of course if no be say ur oga die, u for no get there. (Of course, were it not for the death of your boss-President Yar'adua, you wouldn't have been there!)

"If I can make it, you can make it!" I no wan make am thru somebody's death oo

(I don't want to make it [i.e., achieve your feat] as a result of the death of somebody)

I believe that the young man did not really mean any insult. His NPE rendition is for "jocular effect" (Jowitt, 1991). However, beneath this humour is an aura of frustration and indignation to the system of governance (in Nigeria) which offers no hope for tens of thousands of corps members like this commentator. His last statement, italicised in the above excerpt, betrays this assertion.

\section{Background of the Nigerian Politics}

Ethnic and class struggles have characterised the Nigerian polity, policy and politics right from the time Lord Luggard merged the Northern and Southern protectorates in 1914. A good example was the motion for independence moved by a southerner, Pa Anthony Enahoro, which was not supported by Sir Ahmadu Bello, a northern fellow compatriot due to what he considered the imbalance in educational status between the South and the North. Nigeria's ethnic groups are estimated to be about five hundred, and so, tribal difference seems to be an impenetrable barrier as years of intermarriage have proved ineffective dossier to this problem. Closely trailing the ethnic obstacle to nationism and nationalism is the religious faith of the people. Islam and Christianity are predominant in the northern and southern parts respectively. The high class is constituted by the retired and serving public office holders mostly found among the Hausa, Yoruba and Igbo major tribes. Thus, the social stratification is wide and unevenly distributed in terms of wealth and education.

The post-colonial political era in Nigeria further brought into limelight the multiple complexities among the inhabitants. Some political analysts observe that, perhaps, the country as a nation only exists only on paper (map) and on certain occasional circumstances. Others even paradoxically put it that no English, no Nigeria. All these comments point to one thing - the fragile national cohesion among the component indigenes in addition to the corruption, ethnic alliances and cleavages that pervades the fabric of the society.

These situations of power dominance, hegemony, ideology, class, ethnicity, and many other interests in the society are capitalised on by politicians in Nigeria to manipulate the people, win their votes, and consequently control them. The effect, among others, is the election of incompetent leaders into public offices. However, globalisation resulting from the internet, television and other communication gadgets as well as the increasing level of education is impacting positively on all nations in terms of awakening their consciousness especially in the third world countries like Nigeria. Television advertisements give a good image of a contestant in a well-packaged manner. This phenomenon prompts this writer to appraise political campaigns television adverts beyond the borders of what the speaker wants them to mean to what the hearers think they could mean. This paper analyses this multi-modal discourse within the context of politics and applies general principles of critical discourse analysis to expose the subjectivity in the seemingly objective positive packaging of television advertisements.

\section{Critical Discourse Analysis in a Multi-Modal Discourse}

Critical Discourse Analysis (henceforth, CDA) entails detailed analysis that explains and uncovers the ideological assumptions that are hidden in the words, (Habermas, 1973). CDA primarily focuses on socio-political issues which are rather beyond the textual border itself. It employs analytical tools which include both linguistic and non-linguistic parameters to address societal challenges relating to class, gender and culture. Matters like social relations, objects and instruments, time and place, belief system, societal values and knowledge are the paradigms used to unravel hidden reasons behind utterances or statements.CDA, is thus close to social semiotics with a thin line of demarcation. Social semiotics, according to Hodge and Kress (1988), studies meaning design and interpretation. This covers the study of how semiotic systems are shaped and adapted by social interests and ideologies. Halliday \& Matthiessen (2004) consider language as a functional medium which incorporates a number of semiotic systems organised and described through three fundamental metafunctions: the ideational metafunction accounts for the representation and interconnectivity among various semiotic resources; the interpersonal meta-function describes the role-relations between the addresser of the addressee while the textual metafunction describes various ways by which cohesion can be achieved in a 
multimodal texts.

According to Fairclough, Jessop \& Sayer (2004), CDA varies in theory, methodology, technique and its thematic preoccupation and it finds an ally in systemic functional linguistics. (see also Dellinger, 1995; AbdullahiIdiagbon, 2009). Halliday (1985) argues that lexical and grammatical features of texts are encapsulated in trio discourse field, tenor and mode. He asserts that the field portrays the social and natural world; tenor constructs social relations while mode focuses on how coherence is achieved through a channel. It is in within this context that we intend to examine the impacts of a multi-modal channel of encoding a campaign advert and its implications in terms of how it is encoded and decoded by the speaker and hearers respectively.

Thus, the task of CDA is both deconstructive and constructive. In its deconstructive moment, it aims at exposing the issues of power relations in both written and spoken discourses. CDA addresses how discourse structure is used to enact, confirm, legitimise, reproduce or challenge ideological and historical issues (Fairclough \& Wodak, 1997: pp. 271-280) CDA tries to unite and determine the relationship between the actual text, the idea behind it and the larger social context that serves as a plausible and possible platform for its interpretation. It thus employs interdisciplinary techniques to look at how texts construct representations of the world, social identities, and social relationships. On the other hand, in its constructive perspective, it does not have a unitary theoretical framework but tries to ask questions about the way specific discourse structures are deployed in the reproduction of social dominance, whether they are part of a conversation, a news report or other forms of a discourse.

Although Van Dijk (1991) emphasises that CDA provides critics with a tool for studying communication within socio-cultural contexts and how ethnicity affects our ideological thinking as well as utterances. Van Dijk states that conversations reflect the cognitive, social, historical, cultural, or political contexts. Therefore, Thompson (2002) like Fiske (1994) warns that we should not consider utterances neutral; rather we should be conscious of the underlying meaning of the words. Our words are politicized, deliberately or not. Likewise, institutions or individuals like courts, government and academics play a crucial role in defining legitimacy or illegitimacy of issues.

CDA has an "overtly political agenda" aiming at providing accounts of the production, internal structure, and overall organization of texts" (Dellinger, 1995). Fairclough (1992b) argues earlier that those groups who control most influential discourse also have more chances to control the minds and actions of others. Action is controlled by our minds, which, in turn, is influenced by our utterances and statements. For instance, threats and persuasions will definitely come as reactions to the way our minds interpret certain expressions. While some people only have active control over everyday talk, others are more or less passive targets of text or talk. For instance, bosses simply tell their subordinates what to do or believe or what not to. One may then be prompted to ask the following questions:

a. How do (more) powerful groups control public discourse?

b. How does such discourse control mind and action of (less) powerful groups, and what are the social consequences of such control, such as social inequality? On the other hand, members of more powerful social groups and institutions, have more or less exclusive access to, and control over one or more types of public discourse. Those who have more control over more discourse are, by that definition also more powerful. All these discursive practices are embedded in a multimodal discourse in order to create particular kinds of meanings. It is a strategic approach for studying how meanings occur through the interaction of the linguistic text, visual image as well as historical representation

One crucial difference is that CDA seeks to provide a critical dimension in analysing a text as well as their textual imports which, in a way, gives clue about who the voice belongs to, such as elected politicians, corporation presidents, union leaders, bureaucrats, laborers, criminals, etc. According to Fairclough, Jessop \& Sayer (2004), CDA varies in theory, methodology, technique and its thematic preoccupation. (see also Dellinger, 1995; Abdullahi- Idiagbon, 2009). Halliday (1985) argues that lexical and grammatical features of texts are encapsulated in trio discourse field, tenor and mode. He asserts that the field portrays the social and natural world; tenor constructs social relations while mode focuses on how coherence is achieved through a channel. It is in within this context that we intend to examine the impacts of a multi-modal channel of encoding a campaign advert and its implications in terms of how it is encoded and decoded by the speaker and the hearers respectively. This is because not only will a multimodal means offer a broad opportunity to study a message but also because emphasis is rapidly shifting from monomodality to multimodality channel of communication.O'Halloran, Tan, Smith, and Podlasov, A. (2009, p. 19) observe that

discourse analysts are increasingly required to account for multimodal 
phenomena constructed through language and other resources (e.g. images,

sound and music) and to relate higher-level critical insights on the social

motivations of these texts to their realizations in lower-level expressive

phenomena, and vice versa.

These scholars maintain that not only does a discourse ultimately determine how it is to be interpreted but also serve as a tool to measure the analyst's own competence and expertise through the amount of critical insights available to him as noticed in the analysis of such discourse.

\section{Analysis}

This paper attempts to account for the immense complexities of multimodal communication television campaign advert by examining the effects of multiple communicative strategies and means in the meaning conception and perception. Through carefully selected terms, Jonathan's speech is emotion-laden. This is manifest in his facial expression and gestures. This perfect manoeuvre of ideational language metafunction with the appropriate paralinguistic cues results in textual cohesion. He sees the masses and himself as having the same destiny path. To demonstrate this, visual images of artisans of different Nigerian ethnic backgrounds are shown to match his utterances.

According to Broadwell and Thompson (2004, pp. 128-129), film makes us assume that information about the world in which we live are factual. Jonathan's advert does this for specific effects. He recollects the multitude of challenges he had to face in his childhood in terms of his inability to meet the basic needs of life like shoes and school bags which he lacked. This, he believes, will make him be responsible and responsive to the masses. All this suggests a connotative rather than a denotative appraisal of the advert. This experience took place at about five decades ago: Jonathan has since come to political limelight a decade ago rising from a state legislator to a deputy governor, then to a state governor. Later, he became the Vice President to the late President Yar'adua and now the substantive President having won the 2011 presidential election in Nigeria. It is not uncommon for the people in power or politicians to employ this type of rhetorics to persuade people. A critical study of this discourse prompts the analyst to reject such simplistic peripheral interpretation or assumptions of such interpretation. Instead, the analysts explore the socio-political situations underpinning constructs of this discourse and their contextual use. The citizens are framed within an ideology which, in turn, impacts on the lives, contentions and contestations of basic human needs.

In spite of the huge material and human resources the country is blessed with and which should ordinarily usher in the desired socio-political and economic prosperity, It is noteworthy that as at the time he was the deputy governor and later the governor of Bayelsa State, Jonathan was not distinguished for unique people-oriented programmes neither was his impacts significantly felt during his three years of Vice Presidency under his cool-headed boss. Therefore, the content of his speech is more of politicking than a resolution.

The use of past tense was in I was not born rich is quite significant though not necessarily new information. Over $70 \%$ of the Nigerian populace, most of who are peasant farmers, fishermen and artisans, live in poverty across cities and villages. The images of this class of people which Mr. President claims to be identifying with as represented by their images captured to indicate the humble beginning of Mr. President. Jonathan's case is therefore not unusual as the advert is making it to be; the information is to wield sentiments.

Constitutionally, being wealthy is not a condition for becoming president though, in Nigeria, a lot of money is lavishly spent to buy electorates and perpetrate acts of electoral malpractices. This type of meaning potential which conveys information about the qualities of the participants, their social status, race, class, type, and/or position is known as conceptual representation or relational processes (Halliday, 1994. Van Leeuwen, 2001).

Similarly, I had no shoes is a further demonstration of poverty and low class - the trace which has so far disappeared in Jonathan. Poverty is, here, made a credential to groom a potential good administrator since the speaker is thematising poverty. A political landscape reflective of South-south geo-political zone, from which Jonathan comes, is shown to depict the miserable conditions of living of the inhabitants. A dim-light coupled with a ghetto-like environment and poor children are images used to depict the humble beginning of Mr. President. The denotative meaning here is presented as 'self-evident' information by means of visual stereotypes ,e.g., clothing and appearance for instance, or symbolic attributive processes which is used to encode 'what a participant means or is' (Kress \& van Leeuwen, 2006, p. 105).

The relevance of the above information to this present situation is in question; the spacio-temporal relevance of information presentation is foregrounded here. In Nigeria, political office is a platform to amass wealth. The 
implication here is that the speaker's recent exposure to luxury and power might be intoxicating thus, turning him against the people he is making a promise to serve. The persuasive tone is targeted towards the poor and mostly the uneducated, which constitute the majority of the electorates.

Electorates in Nigeria cast their votes along socio-cultural and religious sentiments. It is therefore part of his political strategy to appeal to them through this strategy as shown in the next pictures. The interrelationship between the visual and verbal modes is crucial to the meaning being projected to the viewers. People dressed in different ethnic attires and religious affiliations are shown, all unanimously proclaiming "I am Goodluck Jonathan" as shown in these advert images.
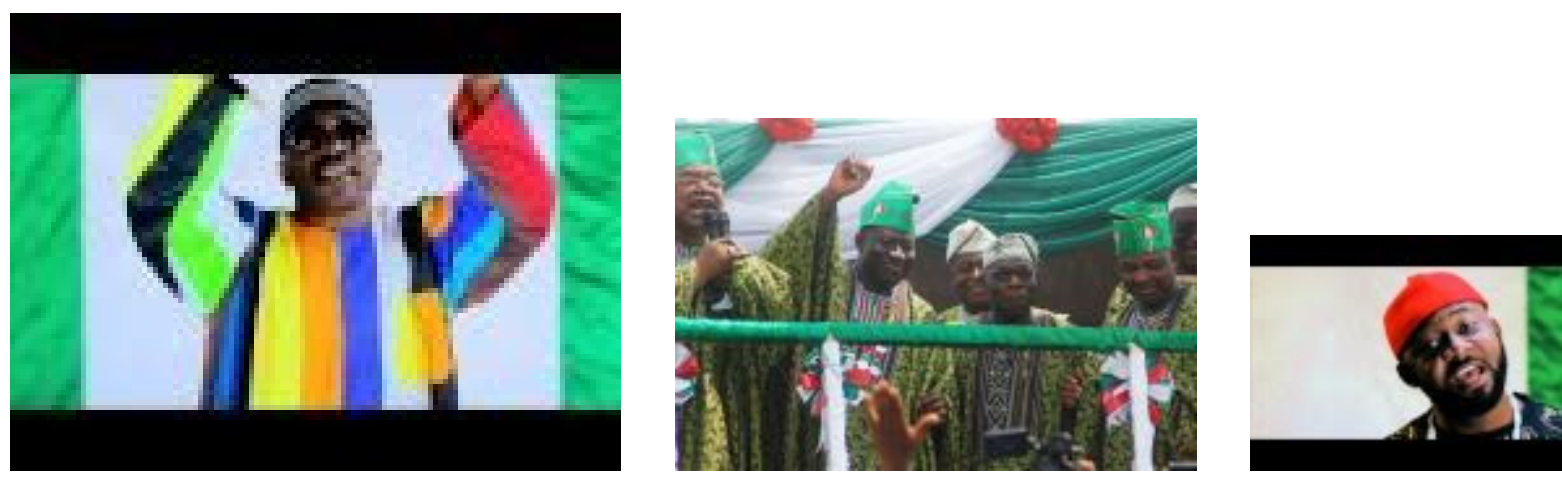

Figure 1. I Am Goodluck Jonathan

As the Vice president for three years and President for a year before his re-elections, Jonathan has got tremendous influence and ample opportunity to turn around the economy of Nigeria especially through the so-called 7-points agenda of Yar'adua/Jonathan's administration. Nigerians, up till now, are being promised what they were promised five years ago! The advert says little or nothing about economic issues. Though a tripartite division of communication into text, sound and nonverbal elements, there is an attempt to interpret text by combining and integrating such meaning-making processes as sound, gesture, movement and visual images to produce "a text-specific meaning" (Thibault, 2000: 311).

The analysis of the simple sentence "I am one of you." is critical in many ways: first, is the simple present tense form of the verb am, and second is the second person singular pronoun you. That Jonathan is comparing his present status with whoever you could be referring to is unconceivable and politically-instigated. Below is a sketch of the possible conception of the contextual use of the pronoun you in I am one of

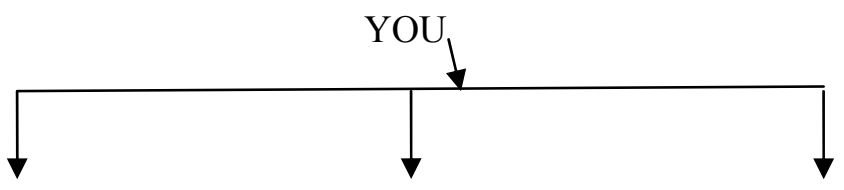

Ordinary Nigerian masses

Fellow Nigerians

Every individual

Figure 2. Possible interpretations of the pronoun YOU as used in the speech

By this statement, I have no enemies to fight, the speaker attempts to appeal to the minds of the electorates so that he can inadvertently control their actions. The political climate is tense, and the people in upper class, who have things to hide, or personal conviction that Jonathan is possibly on a revenge/ vengeance mission are the first category of the potential enemies. Secondly, being a multi-religious country, Nigeria has witnessed many horrible instances of religious riots most especially in the northern part of the country. Religious intolerance is therefore an endemic characteristic and is more often a determinant in the Nigerian election.

It is also plausible to assume that the so-called enemies are the Northern political mafia which is not happy that the northerners had been deprived of what was supposed to be the second term ticket of the deceased President Yar'adua. The ruling party manoeuvred the party's zoning formula in favour of President Jonathan's presidential aspiration. This innuendo was expressed by the majority of the people in the north-central geo-political zone who massively declared their support for the presidential bid of their so-called "consensus" candidate during the PDP 
presidential primary, Atiku Abubakar. Perhaps this category of people also considers Jonathan a potential threat.

Past political leaders are hunted by their past misdeeds while in office as a result of which they actively get involved in determining who win elections into the state and federal political offices in order to cover up their corrupt practices. In this case, the statement is a form of assurance that if elected, he poses no threat to them their secrets are safe! Ruling class-interests determine the superstructure and the nature of feasible ideology because the ruling class controls the means of production. He is shown to identify with president Obama to strengthen his international relevance, credibility and acceptability. Like Obama, his statement "I was raised by my mother and father with just enough money to meet our daily needs". Obama's technique is also a psychological manipulation. This common childhood experience and the noble family background are well foregrounded. One must understand the science behind the language patterns in order to spot them. Multimodal discourse analysis equips the analyst to reject the simplistic face- value interpretation of signs and utterances by juxtaposing the analysis the social practices and their use within the discourse side by side with the empirical situation.

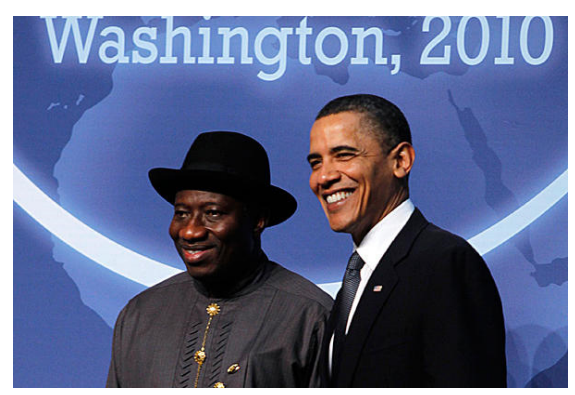

Figure 3.

However, on the contrary, the anti- Biafra elements during the Nigerian civil war are either not confident that, a south-south or south-east candidate will not attempt a secession or will not ask for a pound of flesh from the remnants of anti-Biafra veterans if an opportunity presents itself. All the aforementioned are potential enemies but who, according to Mr. President, are not considered enemies. What about the enemies of the State policies, the cogs on the wheels of the nation's development - are they not also enemies worthy of being fought? The President seems to conceive enemies as being personal. This is so because an individual or an organisation that strives for power will try to influence the ideology of a society to become closer to what they want it to be.

As observed by Fairclough \& Wodak (1997: 271-280), those people who control most influential discourse also have more chances to control the minds and actions of people. CDA focuses on the abuse of such power, and especially on dominance, that is, the ways control of discourse is used to control people's beliefs and actions in the interest of dominant groups, and against the best interests or the will of the others. Class stratification entails social inequalities that give the superstructure, the powerful class, so much influence on the resources of the nation. The masses are at the receiving end as there is inequality and exploitation within the supposedly one nation.

Multimodal discourse analysis opens access to a form of analysis answerable to the social practices which underlie and construct of both signs and their use within discourses. However, ultimately, whether explicitly acknowledged or not, critical insights into text are dependent upon both the texts themselves and the readings applied by analysts, and here the analyst's own metadiscourse becomes the site for critical 'self-reflexion' (making one's own analysis the site of further critical analysis). Furthermore, such insights must be implementable in and answerable to empirical analysis, a challenge that becomes even more apparent when working within an interactive digital environment.

It is of interest when the President proclaims that I never imagined I could be where I am today. One is tempted to ask "why?" The statement, in a way, contradicts I am one of you earlier uttered. Has the speaker no constitutional right to contest for an elective position? Is he a simpleton as it is being insinuated by some people? Is this is a sign of defeatist tendency or incompetence in the murky socio-political terrain of the Nigerian politics? This statement and others earlier cited in this work credited to the aspirant -Jonathan- call for explanation on what it actually takes to become the President of the federal republic of Nigeria. There is virtually nothing to suggest the credible credentials of a contestant for Presidency in Nigeria. The fact is that the nation's problem stems from the misconception and misrepresentation of what leadership and power are. Politicking in Nigeria is just like hunting in an unknown territory. Anything goes. It's either you get killed or you kill to get to the top. 
Instead, Religion is a strong ideological factor used in the Nigerian society to induce and arouse solidarity: this type of solidarity though may not be total, as it only serves as a divisive factor for partial loyalty. Thus, the prayer for the repose of the deceased, May his soul rest in perfect peace, is to assuage either the northerners or more specifically, the Muslim faithful among the electorates. The intention to demonstrate unfettered sense of subordination to the late President cannot also be ruled out. The statements that immediately follow demonstrate further how the Society has been fragmented on the constitutionality of the Vice President to take over the mantle of leadership under certain circumstances like the situation of incapability of the President. The case is now between the Constitution and the constituency (the North). The National assembly influenced by the larger society failed to implement the change-over clause until the situation was becoming chaotic. This "very trying times" threatened the "national security."

Lastly, the complex sentence, If I can make it, you can make it, the second clause, which is the main clause, topicalises hope and assurance to every Nigerian. He urges people to take a cue from him and his antecedents. There are other factors unmentioned by the speaker which have, perhaps, helped in his own case to achieve his present feat. For instance, the speaker's educational status and involvement in politics are privileges many Nigerians may not be able to enjoy or experience. But the unfortunate thing here is that majority of Nigerians are illiterates. UN states that about $20-30 \%$ of Nigerians are educated to an acceptable degree. The rest, which constitute the majority, are somewhat illiterates. That informs why the constitutional duty of the Senate is conceived to be a favour. Jonathan, like any other African leader, sees the office of presidency as a powerful one which makes both the state and public apparatus and facilities at his disposal. Thus, he did not hesitate to appreciate the role played by the National Assembly, Governors, Civil Society groups, the mass media, and other patriotic Nigerians. This act, as far as he is concerned, is the concept of patriotism and care.

Many frontline northern politicians, especially those seemingly disenfranchised in the ruling party see-saw game, strongly canvassed for continuity of the late Yar'adua's government to be headed by another fellow northerner within the party during what was supposed to be his second tenure were he alive. They even had a consensus candidate in the party primary against Jonathan. Hence, this so-called position of the northerners is questionable and misguided. The advert, through the utterances and images of the three major ethnic representations, are portrayed to be consensus in their demand for the presidency of Goodluck Jonathan.

Government policies pass through legislative, judicial and executive processes which often make the pronoun We necessary and courteous. The pronoun $I$ is however repeatedly used when the President was giving a list of his few catalogue of achievements (see the appendix.). Therefore, it is absurd and illogical that with such immense ego associated with the use of first person singular by the President, he could say that he came under intense pressure to make a declaration concerning my political future, but declined to do so because it would have immediately distracted us from all the development initiatives we have accomplished so far. Of course, those mounting the so-called pressure over a position must be benefitting at the expense of other fellow countrymen.

The President acknowledges the deplorable situations of the nation's infrastructure,

unemployment, epileptic power supply, biased judicial system, unstable and poorly financed health- care and educational systems though no illustrative pictures were simultaneously used to accompany this verbal expression. The non-image illustration of these situations is to give it less publicity. If, as the former Vice-President and later President, these problems persist, then, the masses demand explanations from their government. The President uses the modal auxiliary WILL to indicate an obligation and certainty of victory He declares, We will fight. This simple sentence has both logical and grammatical subjects in the personal pronoun $W e$, and the verb fight is a transitive verb but here, the object to fight was not mentioned. Then, one may want to know why Jonathan wants to fight imaginary things instead of the real animate perpetrators and causes of these problems. Certainly, there are sacred cows - those who can make the efforts of successive government's efforts on revamping the economy a mirage - but who cannot be used as scapegoats. So, by implication, if causes of a problem are not identified and properly addressed, the problems will persist.

\section{Conclusion}

Politicians canvass for votes and in a bid to woo electorates, it is now clear that it takes more than gift of the gab or playing to the gallery to achieve this aim. Rather, the audience's insatiable appetite for information and the truth that have bearing in their lives need to be told. Politicians are really in a good position to offer these needs but not all of them will be pleasant to the audience. Therefore, some pieces of information are withheld or recast by the speakers by manipulating words and other modes in a multimodal discourse to suite their own objectives while at the same time making the utterances seem more pleasant for acceptability. The power in a discourse lies on the superstructure class of the society whose utterances are treated and seen as the gospel truth because the 
control of media and many other institutions through which information can reach people are designed to serve the interest of the upper class.

The inequality and dominance in resource control confer power and influence on certain people to dictate where the pendulum swings not necessarily by force but by voice. Thus, as the readers read or listen to or watch a discourse, they should dichotomise btw the facts and falsehood, and that opinion and is not necessarily factual but the design and production of a communicative message do affect thinking and interpretation. It is always the desire of the bourgeoisie to make trivial crucial and crucial trivial. Ideology is an idiosyncrasy and should therefore not be a tool to be used for general conviction. Caution and meticulousness are watchwords to wade through the murky stream of words of an individual, which are full of subjectivity.

\section{References}

Abdullahi-Idiagbon, M. S. (2009). Structure and meaning in English: A discourse analysis of Nigerian legal documents. A Doctoral dissertation. Department of English, University of Ilorin.

Dellinger, B. (1995). A critical cross-cultural analysis of the American commercial discourse style. Vaasa: Universities Wasaensis.

Fairclough N. (1992b). Discourse and social change. Polity Press: Cambridge.

Fairclough N., Jessop B., \& Sayer A. (2004). Critical realism and semiosis. In J Joseph, \& J Roberts Realism (eds.), Discourse and Deconstruction. Routledge.

Fairclough, N., \& Wodak, R. (1997). Critical Discourse Analysi. In van Dijk, T. A. (eds.), Introduction to discourse analysis (pp. 258-284). London.

Fiske, J. (1994). Media matters everyday culture and Political Change. Minneapolis: University of Minners of Press.

Haberman, J. (1973). Theory and practice. Boston: Beacon.

Hall, S. (1996). The meaning of New Times. In Morley D., \& Chen K. (eds.), Stuart Hall: Critical Dialogues in Cultural Studies. Routledge, London.

Halliday, M. A. K. (1985). Language, context and text: Aspects of a language in a social- semiotic perspective. Geelong: Deakin University Press.

Halliday, M. A. K., \& Christian M. I. M. Matthiessen. (2004). An introduction to functional grammar (3rd ed). London: Edward Arnold. Retrieved from http://naijanedu.com/bluecrystalsinc@gmail.com

Huckin, T. N. (1997). Critical discourse analysis. In T. Miller (Ed.), Functional approaches to written text. $\begin{array}{llll}\text { Retrieved } & \text { March } & 603 & \text { from }\end{array}$ http://exchanges.state.gov/education/engteaching/pubs/BR/functionalsec3_6.htm

Jowitt D. (1991). Nigeria English usage - an introduction. Ikeja: Longman.

The Best Nigerian Political Ad Campaign - Let God's Will Be Done. GOODLUCK JONATHAN. http://www.youtube.com/watc...

Thompson, M. (2002). ICT, power, and development discourse: A critical analysis. Retrieved March 6, 2003 from I Am Goodluck Jonathan -The Best Nigerian Political Ad Campaign http://www.jims.cam.ac.uk/research/seminar/slides/2003/030529

Van Dijk, T. (1991) Racism and the press. In Robert Miles (Ed.), Critical studies in racism and migration. New York: Routledge.

\section{Appendix}

SPEECH BY THE PRESIDENT OF THE FEDERAL REPUBLIC OF NIGERIA, DR. GOODLUCK EBELE JONATHAN, GCFR, ON THE OCCASION OF THE DECLARATION OF HIS CANDIDACY FOR THE PDP PRESIDENTIAL PRIMARIES, TODAY 18TH SEPTEMBER, 2010.

\section{PROTOCOL}

Forty months ago my predecessor in office and I embarked on a joint ticket in the governance of our great country, Nigeria. Sadly, he passed away on the 5th of May 2010. MAY HIS GENTLE SOUL REST IN PERFECT PEACE, AMEN. With the death of President Umaru Musa Yar'Adua, the mantle of leadership of our great nation fell on me. However, the days leading to my presidency were very trying times for our nation. We confronted those moments and their challenges to national security with patriotism and care. I appreciate the 
role played by the National Assembly, Governors, Civil Society groups, the mass media, and other patriotic Nigerians.

The late President Yar'Adua and I shared great dreams for our country. We toiled together to realize those dreams in order to justify the confidence Nigerians reposed in us. Together we swore to execute a joint mandate and today I come before you to make a pronouncement based on that undertaking.

The past four months that I have served as President of Nigeria have opened my eyes to the vast potentials of this office as a potent instrument for the transformation of our country. I discovered that by sheer willpower, I could end the long queues and price fluctuations in our petrol stations. Today, all our refineries are working, saving us huge amounts of funds spent on importation of petroleum products.

I discovered that by insisting that the right things be done, we could begin a turnaround in our power sector by involving the private sector in power generation and distribution. As you can see from the lower quantities of diesel that you are buying today, power generation has significantly improved.

I have put in place new gas policies and very soon, we will be saying goodbye to gas flaring in our oil fields. Working with the National Assembly, we rolled out a law that requires companies operating in the oil and gas sectors of our economy to utilize an appreciable percentage of their goods and services from local sources. We saw to it that normalcy began to return to the Niger Delta by ensuring government's fidelity to its promises, and this has helped to stabilize our national revenue.

In the last few months, I embarked on monumental projects in our road infrastructure to end the carnage on our federal highways. I began several projects to make our water resources available for drinking and farming. I targeted our educational system to return quality and competitiveness to them. I re-addressed our drive for self sufficiency in food production. I have taken bold steps to confront our security situation. In this regard, we are pursuing the revision of our laws to be more responsive to international conventions and more punitive to criminals.

I set the stage for free and fair elections by constituting an electoral commission comprising of Nigerians with impeccable credentials for firmness and incorruptibility. I charged our anti corruption agencies to speed up the war against corruption, and respect no sacred cows in the process. In the management of the economy, I advocated a more transparent banking industry, price stability, low inflation, and aggregate increase in productivity as a way to drive us to a more prosperous economy. In International Relations, I advanced the respectability accorded our country by effective engagement in global fora.

From the moment I was sworn in as President, I came under intense pressure to make a declaration concerning my political future, but declined to do so because it would have immediately distracted us from all the development initiatives we have accomplished so far. As President and leader of this government, I decided not to place partisan politics above the immediate needs and priorities of our people. I therefore told Nigerians to give me time to concentrate on my work, and that at the appropriate time, I would make a public statement on my political future after widespread consultations.

Those consultations have now been concluded. The Independent National Electoral Commission has recently announced a time table for the 2011 general elections in the country. My party, the Peoples Democratic Party, has also published a timetable for its primaries.

In the circumstances and after a thorough self examination and prayers with my family, I, Goodluck Ebele Azikiwe Jonathan have decided to humbly offer myself as a candidate in the Presidential Primaries of our great party, the Peoples Democratic Party, in order to stand for the 2011 Presidential elections. I pledge once again to all the people of this nation that they will have a free and fair election, even as I stand to be a candidate. In this race, I have the honour to have as my running mate, Architect Namadi Sambo, the Vice President of the Federal Republic of Nigeria.

Our country is at the threshold of a new era; an era that beckons for a new kind of leadership; a leadership that is uncontaminated by the prejudices of the past; a leadership committed to change; a leadership that reinvents government, to solve the everyday problems that confront the average Nigerian. I was not born rich, and in my youth, I never imagined that I would be where I am today, but not once did I ever give up. Not once did I imagine that a child from Otuoke, a small village in the Niger Delta, will one day rise to the position of President of the Federal Republic of Nigeria. I was raised by my mother and father with just enough money to meet our daily needs.

In my early days in school, I had no shoes, no school bags. I carried my books in my hands but never despaired; no car to take me to school but I never despaired. There were days I had only one meal but I never despaired. 
I walked miles and crossed rivers to school every day but I never despaired. Didn't have power, didn't have generators, studied with lanterns but I never despaired. In spite of these, I finished secondary school, attended the University of Port Harcourt, and now hold a doctorate degree.

Fellow Nigerians, if I could make it, you too can make it!

My story is the story of a young Nigerian whose access to education opened up vast opportunities that enabled me to attain my present position. As I travel up and down our country, I see a nation blessed by God with rich agricultural and mineral resources and an enterprising people. I see millions of Nigerians whose potentials for greatness are constrained by the lack of basic infrastructure. I see Nigerians who can make a difference in the service of their country but are disadvantaged by the lack of opportunities.

My story symbolizes my dream for Nigeria. The dream that any Nigerian child from Kaura- Namoda to Duke town; from Potiskum to Nsukka, from Isale-Eko to Gboko will be able to realize his God-given potentials, unhindered by tribe or religion and unrestricted by improvised political inhibitions. My story holds out the promise of a new Nigeria. A Nigeria built on the virtues of love and respect for one another, on unity, on industry, on hardwork and on good governance.

My fellow Nigerians, this is what has brought me to Eagle Square today. I have come to say to all of you, that Goodluck Ebele Azikiwe Jonathan is the man you need to put Nigeria right. I have come to launch a campaign of ideas, not one of calumny. I have come to preach love, not hate. I have come to break you away from divisive tendencies of the past which have slowed our drive to true nationhood. I have no enemies to fight. You are all my friends and we share a common destiny.

Let the word go out from this Eagle Square that Jonathan as President in 2011 will herald a new era of transformation of our country; an era that will end the agony of power shortage in our country. Let the word go out from here that I will be for the students, teachers and parents of Nigeria, a President who will advance quality and competitive education. Let everyone in this country hear that I shall strive to the best of my ability to attain self sufficiency in food production.

Let the word go out that my plans for a Sovereign Wealth Fund with an initial capital of \$1billion will begin the journey for an economic restoration. This restoration will provide new job opportunities and alleviate poverty. Let the word go out that our health sector will receive maximum priority in a new Jonathan administration, a priority that will ensure maximum health care and stop our brain drain.

Let all the kidnappers, criminal elements, and miscreants that give us a bad name be ready for the fight that I shall give them. Let the ordinary Nigerian be assured that President Jonathan will have zero tolerance for corruption. Let the international community hear that today I have offered myself to lead a country that will engage them in mutual respect and cooperation for the achievement of international peace and understanding.

To help me in these tasks effectively, I will re-train, revamp, and motivate the civil service.

My dear good people of Nigeria, I got here today by the power of God and the support of all Nigerians; all ethnic groups, North, South, East and West. I am here today because of your support and prayers. I want all of you to know that I am one of you and I will never let you down! I want you to know that I will keep hope alive; I want you to know that your time has come.

I stand before you today, humbly seeking your support for me, Goodluck Ebele Azikiwe Jonathan, to run for the office of the President of Nigeria with Architect Namadi Sambo as my running mate.

We will fight for JUSTICE! We will fight for all Nigerians to have access to POWER!

We will fight for qualitative and competitive EDUCATION! We will fight for HEALTH CARE REFORMS!

We will fight to create jobs, for all Nigerians! We will fight corruption! We will fight to protect all Citizens!

We will fight for your rights!

My dear country men and women, give me your support, give me your votes and together we will fight to build a great nation of our dreams! I cannot end this speech without thanking you all for attending this occasion. Your huge attendance is a loud testimony of your support for us. For this I am very grateful. I pray that the Almighty God abides with you and sees you safely back to your respective destinations.

When you return, tell all those at home that as we celebrate our fifty years anniversary as a nation, Goodluck has come to transform Nigeria and I will never let you down. 